\title{
Relationship of soil potassium forms with maize potassium contents in soils derived from different parent materials
}

\author{
Rashid Mehmood Butt, ${ }^{1}$ Mohammad Saleem Akhtar, ${ }^{1}$ Ayaz Mehmood, ${ }^{2}$ Muhammad Imran, ${ }^{1}$ \\ Shah Rukh, ${ }^{1}$ Ghashiya Sattar Kayani, ${ }^{1}$ Muhammad Tariq Siddique, ${ }^{1}$ Kashif Sarfraz Abbasi, ${ }^{3}$ \\ Abdul Qayyum, ${ }^{2}$ Zahoor Ahmad ${ }^{2,4}$ \\ ${ }^{1}$ Department of Soil Science \& SWC, Pir Mehr Ali Shah-Arid Agriculture University, Rawalpindi; \\ ${ }^{2}$ Department of Agricultural Sciences, University of Haripur, Haripur; ${ }^{3}$ Department of Food Technology, \\ Pir Mehr Ali Shah-Arid Agriculture University, Rawalpindi, Pakistan; ${ }^{4}$ Department of Agriculture and \\ Biological Engineering, University of Florida, Gainesville, FL, USA
}

\begin{abstract}
Understanding of soil potassium $(\mathrm{K})$ dynamics is essential for sustainable crop production. Bioavailability of $\mathrm{K}$ depends on forms and distribution within the soil profile. The objectives of this research were to determine which soil $\mathrm{K}$ forms control the maize (Zea mays) $\mathrm{K}$ contents and compare the extracting capability of sodium tetraphenylborate (NaTPB) with ammonium acetate $\left(\mathrm{NH}_{4} \mathrm{OAc}\right)$ method. Nine soils representing three different parent materials, i.e. loess, sandstone and shale were sampled at three surface genetic horizons. Within each parent material, three soils at varying level of development were selected. Besides basic soil parameters, $\mathrm{K}$ was fractioned into water soluble $\mathrm{K}$, exchangeable $\mathrm{K}$, non-exchangeable $\mathrm{K}$, and NaTPB-extracted $\mathrm{K}$. The maize was sown in pots having $2 \mathrm{~kg}$ soil from each genetic horizon. Crop was harvested at seven weeks and plant was analysed for $\mathrm{K}$ contents. Results show that NaTPB-extracted $\mathrm{K}$ gave best correlation as compared to $\mathrm{NH}_{4} \mathrm{OAc}$ method. This conveys that a non-exchangeable $\mathrm{K}$ portion that becomes available to plants can be better estimated by NaTPB method than $\mathrm{NH}_{4} \mathrm{OAc}$ extraction.
\end{abstract}

Correspondence: Ayaz Mehmood, Department of Agricultural Sciences, University of Haripur, Haripur University Road, 22640 Haripur, Pakistan.

E-mail: ayaz.gill@uoh.edu.pk

Key words: Potassium forms; Potassium availability; Parent material; Soil genesis; Maize.

Received for publication: 3 August 2016.

Revision received: 16 December 2016.

Accepted for publication: 17 December 2016.

(C) Copyright R.M. Butt et al., 2017

Licensee PAGEPress, Italy

Italian Journal of Agronomy 2017; 12:818

doi:10.4081/ija.2017.818

This article is distributed under the terms of the Creative Commons Attribution Noncommercial License (by-nc 4.0) which permits any noncommercial use, distribution, and reproduction in any medium, provided the original author(s) and source are credited.

\section{Introduction}

Potassium is a macronutrient that affects plant growth, quality of grains and fruits. Potassium plays an essential role in plant metabolism (Ruiz and Romero, 2002). In Pakistan, most soils contain relatively large amounts of $\mathrm{K}$ occurring as a structural element of primary minerals, i.e. K-feldspar, muscovite, biotite and illite (Akhtar, 1989), and only a small fraction is present in plant available form. Availability of $\mathrm{K}$ is controlled by its release from $\mathrm{K}$ bearing minerals (mica, feldspar) and fixation by partially weathered mica and vermiculite, and high charge smectite. Potassium release from soil minerals depends on their contents, types, structural properties and particle size distribution. The structural properties of 2:1 type clay minerals controlling $\mathrm{K}$ fixation are layer charge density and charge location. The order of ease of $\mathrm{K}^{+}$expulsion from different minerals by oxalic and citric acids is biotite $>$ microcline $>$ orthoclase $>$ muscovite (Song and Huang, 1988). Soils that contain partially weathered mica, vermiculite or high charge smectite as the dominant clay minerals are usually low in soil solution $\mathrm{K}$. Whereas $\mathrm{NH}_{4}^{+}$fertilisation enhances $\mathrm{K}$ availability as they occupy $\mathrm{K}$ adsorption sites in clay minerals (Kilic et al., 1999).

The clay fraction also comprises kaolinite, montmorillonite, chlorite, and vermiculite (Bajwa, 1989). The soils having sufficient amount of vermiculites and partially weathered mica have capacity to fix an enormous quantity of applied K (Ranjha et al., 1992). The soils of Pakistan have mixed mineralogy. The sand and silt fractions of three Indus river basin soils, i.e. Gujranwala, Peshawar and Lyallpur comprise di and trioctahedral mica, quartz, feldspar and chlorite. Principal minerals in clay fractions are mica, kaolinite and smectite. While chlorite and quartz are also present (Akhtar and Dixon, 2009).

Chemical extractants estimate the fraction of soil $\mathrm{K}$ that plant absorbs but do not assess the natural binding strength of soil particles for $\mathrm{K}$ or the contributive cations like calcium and magnesium. In addition, the electrolyte concentrations of most chemical extractants used to test soil $\mathrm{K}$ are much higher than the soil solute in field soils. Consequently, these high electrolyte concentrations cause an artificial stress on the soil system, resulting indiscriminate extraction of selectively adsorbed K (Herlihy, 1992). Soil K extracted under these circumstances often misrepresents plantavailable $\mathrm{K}$, since some of $\mathrm{K}$ remain un-extracted due to being non-exchangeable but would have available to plants in case of deficiency.

The widely used chemical tests for plant available $\mathrm{K}$ in soils is 
pH 7, 1M ammonium acetate (Hosseinpur and Samavati, 2008). Ammonium acetate remains most widely used test for plant available $\mathrm{K}$ in soil extracts, water soluble and exchangeable $\mathrm{K}$ (Cox et al., 1999) and may cause overestimation in case non-exchangeable $\mathrm{K}$ is also being extracted. Salts or dilute acids extracts lesser K than those extracted by $1 \mathrm{M} \mathrm{NH}_{4} \mathrm{OAc}$ method which suggests that the non-exchangeable $\mathrm{K}$ in soils cannot be evaluated with weak extractants of salts or dilute acids (Simard and Zizka, 1994; Hosseinpur and Sinegani, 2004). Sodium tetraphenylborate can extract both exchangeable and non-exchangeable $\mathrm{K}$ better than $\mathrm{NH}_{4} \mathrm{OAc}$ (Cox and Joern, 1997; Cox et al., 1999). This advantage can increase accuracy in predicting plant $\mathrm{K}$ uptake, especially when plants obtain considerable amounts of $\mathrm{K}$ from nonexchangeable forms. On the other hand, some researchers reported that NaTPB has no advantage compared to the traditional methods for assessment of plant available K (Schindler et al., 2002; Fernandez et al., 2008). The effectiveness of solute used for assessment of available soil $\mathrm{K}$ seems largely dependent on the nonexchangeable $\mathrm{K}$ extracting power and extraction period of the method that different researchers employed. Studies on K extraction through $\mathrm{NaTPB}$, and its comparison with $\mathrm{NH}_{4} \mathrm{OAc}$ extraction method are very scarce. It is hypothesised that the $\mathrm{K}$ extracted by NaTPB may be the better predictor for the bioavailable K than the extracted by other extractants. We sampled soils at different level of development in three different parent materials at three depths level with the purpose of wide range of soil properties. The objectives of the study were to i) assess which soil $\mathrm{K}$ forms controls the maize (Zea mays) $\mathrm{K}$ contents, ii) to compare the extracting capability of NaTPB method with $\mathrm{NH}_{4} \mathrm{OAc}$ method and iii) to determine which method is better to predict the available $\mathrm{K}$ using maize as a test crop.

\section{Materials and methods}

\section{Site description and soil sampling}

The study area is a part of Pothwar Plateau, and lies between latitude $32^{\circ} 35^{\prime \prime}$ and $34^{\circ} 09^{\prime \prime} \mathrm{N}$, and longitudes $71^{\circ} 40^{\prime \prime}$ and $72^{\circ} 59^{\prime \prime}$ E. The parent materials of Pothwar Plateau are loess and the residuum from sandstone and shale. The loess is windblown material from sandy plains deposits on Siwalik sandstone and shale in the region during Pleistocene period, sequences of soil series developed in each parent material were included. Soils are developed in loess and outcrops of sandstone and shale. The Kahuta, Balkasar and Qazian soil series, in order of most developed to least developed soils, form a toposequence in sandstone residuum. The Guliana, Rawalpindi and Rajar soil series is a toposequence in loess. The Muree, Ghoragali and Tirnol soil series are a toposequence in shale residuum. The classification and genesis of these soils are given in Table 1. Soil was collected from three surface genetic horizons and air dried, crushed and then passed through 2 $\mathrm{mm}$ sieve before analyses.

\section{Soil analysis}

The soil properties important for understanding the chemical environment like soil $\mathrm{pH}$ and $\mathrm{CaCO}_{3}$ contents were analysed. Soil $\mathrm{pH}$ was determined in 1:1 (w:v) ratio soil suspension using a $\mathrm{pH}$ meter (model-6071 N; Jenco Electronics, Grand Prairie, TX, USA) after thorough mixing and equilibration of $1 \mathrm{~h}$ (Thomas, 1996). Soil calcium carbonate was estimated by $\mathrm{CH}_{3} \mathrm{COOH}$ consumption (Loeppert et al., 1984).

\section{Soil potassium forms determination}

Soil $\mathrm{K}$ was fractionated into water soluble $\mathrm{K}$, exchangeable $\mathrm{K}$ and non-exchangeable $\mathrm{K}$. Water soluble $\mathrm{K}$ was estimated by extracting with deionised water (Jackson, 1973). Exchangeable K was determined by extracting with $1 \mathrm{M} \mathrm{NH} \mathrm{N}_{4} \mathrm{OAc}$ solution (Knudsen et al., 1996). Non-exchangeable K was determined by boiling soil in $25 \mathrm{~mL} 1.0 \mathrm{M} \mathrm{HNO}_{3}$. The digested residues were filtered and concentration of $\mathrm{K}$ was quantified on flame photometer (model PFP7; Jenway, Stone, UK) using Pratt (1965) method.

The NaTPB-extractable $\mathrm{K}$ was done using the procedure as described by Cox et al. (1999). Briefly, $500 \mathrm{mg}$ soil was putted in $50 \mathrm{~mL}$ centrifuge tubes and mixed with $3 \mathrm{~mL}$ extractant $(\mathrm{NaBPh} 4$ $+\mathrm{NaCl}+0.01 \mathrm{~mol} \mathrm{~L}^{-1}$ EDTA). Mixture was shaken at $200 \mathrm{rpm}$ for $20 \mathrm{~min}$. Later, $25 \mathrm{~mL}$ quenching solution $\left(0.5 \mathrm{~mol} \mathrm{~L}^{-1} \mathrm{NH}_{4} \mathrm{Cl}+\right.$ $0.14 \mathrm{~mol} \mathrm{~L}^{-1} \mathrm{CuCl}_{2}$ ) was added to the tubes to stop the further extraction of soil $\mathrm{K}$. The tubes were heated in water bath for 60 min to dissolve the $\mathrm{KBPH}_{4}$ precipitates. The supernatant was separated by centrifugation at $5000 \mathrm{rpm}$ for $10 \mathrm{~min}$ and filtrate was analysed for $\mathrm{K}$ by using the procedure described earlier.

\section{Pot experiment and plant potassium concentration determination}

About $2 \mathrm{~kg}$ of the soil selected from each horizon was packed in pots. Five uniform weight seeds of maize variety Kashmir gold were sown in each pot. The seedlings were thinned to two plants per pot one week after germination and irrigated with distilled deionised water. Each pot received $200 \mathrm{mg} \mathrm{kg}^{-1}$ nitrogen, $50 \mathrm{mg} \mathrm{kg}^{-}$ 1 phosphorus, $123 \mathrm{mg} \mathrm{kg}^{-1}$ boron, $200 \mathrm{mg} \mathrm{kg}^{-1}$ zinc and $310 \mathrm{mg}$ $\mathrm{kg}^{-1}$ iron. Seven-week old plant was harvested, oven dried at $65^{\circ} \mathrm{C}$, and whole plant (including root and shoot) weighed for biomass. The dry plant material was grounded to powder for elemental analysis. Dry ashing of plant material was done in porcelain crucibles in a muffle furnace at $550^{\circ} \mathrm{C}$ and ash was dissolved in hydrochloric acid. Aliquot was used for $\mathrm{K}$ determination using flame photometer (Chapman and Pratt, 1961).

\section{Statistical analysis}

Soil K extracted with different extractants, and plant K were statistically analysed by multivariate analysis of variance (SAS version 9), where a value in depth-1 to depth-3 dependent upon parent material and soil nested within parent material. Means for soil within parent material and their interactions were compared using t-test $(\mathrm{P} \leq 0.05)$. Correlations between the soil $\mathrm{K}$ forms and plant $\mathrm{K}$ were drawn. The statistical analysis was performed using SAS version 9.

\section{Results and discussion}

\section{Soil characteristics}

Most soils were dark brown to yellowish brown in color except that of shale derived soils being reddish to reddishbrown. The young soils were calcareous without a zone of lime accumulation while the soils at relatively higher development stage were decalcified to variable depths with a distinct zone of lime accumulation. Most soils had $\mathrm{pH}$ greater than 7.0. Soils that are relatively more developed had low $\mathrm{pH}$ at the top, while the young soils had uniform $\mathrm{pH}$ throughout the profile depth (Table 2). Low pH at surface in more developed soils is due to decalcification in soils at higher stage of development (Akhtar 
et al., 2014; Mehmood et al., 2015) while uniform pH throughout the soil profile depth is due to almost uniform calcite distribution in the soil profiles of slightly weathered or young soils (Jamil et al., 2016).

\section{Water-soluble potassium}

Water-soluble $\mathrm{K}$ represents the portion of $\mathrm{K}$ that can be directly removed from the soil solution by plants. The results showed that water soluble $\mathrm{K}$ ranged from 12 to $73 \mathrm{mg} \mathrm{kg}^{-1}$ in the loess soils, 13 to $60 \mathrm{mg} \mathrm{kg}^{-1}$ in the sandstone soils and 64 to $100 \mathrm{mg} \mathrm{kg}^{-1}$ in the shale soils. The hypothesis of non-significant depth $\times$ parent material effect was accepted through MANOVA test criteria (Wilks' Lambda $\mathrm{P}>0.30$ ) suggesting that the difference in parent materials remained statistically nonsignificant at all horizon levels (Figure 1A).

Water-soluble $\mathrm{K}$ contents were higher in surface soil across all the parent material soils. High values of water soluble $\mathrm{K}$ at surface

Table 1. Selected soils in different soil parent materials with United States Department of Agriculture soil classification.

\begin{tabular}{lll} 
Parent material & Soll series & USDA soll classification \\
Loess & Rajar & Typic ustorthents \\
& Rawalpindi & Udic haplustepts \\
& Guliana & Typic haplustafls \\
Sandstone (residuum) & Qazian & Lithic ustipsamments \\
& Balkasar & Typic haplustalfs \\
& Kahuta & Udic haplustalfs \\
\hline Shale (residuum) & Ghoragalli & Typic udorthents \\
& Tirnul & Typic haplustepts \\
& Murree & Typic hapludolls \\
\hline
\end{tabular}

USDA, United States Department of Agriculture horizons could might be attributed to the relatively higher amount of organic matter. The shale-derived soils had greater amount of water soluble $\mathrm{K}$ as compare to loess and sandstone at all depths. The soil at advance stage of development in shale, i.e. Murree soil series had slightly larger amount of $\mathrm{K}$ than the soil at the early stage of development (Ghoragali soil series). Whereas in the sandstone and the loess, the soils at less and moderate development stage had more water-soluble $\mathrm{K}$ and soluble $\mathrm{K}$ increased toward the soil surface in all soils (Table 3 ). The hypothesis of no depth $\times$ soil (parent material) effect was accepted through MANOVA test criteria (Wilks' Lambda $\mathrm{P}>0.72$ ). The water soluble $\mathrm{K}$ was highly and positively correlated with exchangeable $\mathrm{K}\left(\mathrm{r}^{2} 0.97\right)$. Similar results were also reported by Bhaskar et al. (2001), Srinivassarao et al. (2002), Setia and Sharma (2004). The better correlation of water soluble $\mathrm{K}$ with other forms indicates that the water soluble $\mathrm{K}$ was governed by the other forms of $\mathrm{K}$ like exchangeable and total $\mathrm{K}$.

\section{Exchangeable potassium}

Exchangeable $\mathrm{K}$ fraction is portion of $\mathrm{K}$ that is retained by the cation exchange sites on soil particles. Exchangeable $\mathrm{K}$ is in equilibrium with the soil solution $\mathrm{K}$ and may rapidly replenish the soil solution as $\mathrm{K}$ is removed. The exchangeable $\mathrm{K}$ ranged from 19 to $130 \mathrm{mg} \mathrm{kg}^{-1}$ in the loess soils, 21 to $77 \mathrm{mg} \mathrm{kg}^{-1}$ in the sandstone soils and 88 to $154 \mathrm{mg} \mathrm{kg}^{-1}$ in the shale soils. The hypothesis of non-significant depth $\times$ parent material effect was accepted through MANOVA test criteria. Though magnitude of difference among the parent materials at various depths varied, however difference remained statistically similar at all horizon levels.

Exchangeable $\mathrm{K}$ in all three parent material derived soils followed the same decreasing trend with depth (Figure 1B). Further, the soils at higher stage of development in shale had higher content

Table 2. Basic soil properties variation with depth in soils at different development stage in selected parent materials.

\begin{tabular}{|c|c|c|c|c|c|}
\hline Parent material & Soil series & Horizon & Soil texture & Soil pH (\%) & $\mathrm{CaCO}_{3}(\%)$ \\
\hline \multirow[t]{9}{*}{ Loess } & \multirow[t]{3}{*}{ Guliana } & Ap & Silt loam & $7.20(0.46)$ & $1.20(0.23)$ \\
\hline & & Bw & Silty clay loam & $7.40(0.35)$ & $1.00(0.20)$ \\
\hline & & $\mathrm{Bt}$ & Silty clay & $7.50(0.34)$ & $1.20(0.10)$ \\
\hline & \multirow[t]{3}{*}{ Rawalpindi } & Ap & Silt loam & $7.10(0.44)$ & $0.95(0.21)$ \\
\hline & & Bw & Silt loam & $7.40(0.30)$ & $0.75(0.33)$ \\
\hline & & Btk & Silty clay loam & $7.30(0.39)$ & $1.55(0.25)$ \\
\hline & \multirow[t]{3}{*}{ Rajar } & Ap & Silt loam & $8.20(0.30)$ & $14.10(0.32)$ \\
\hline & & Bw & Silt loam & $8.00(0.10)$ & $16.50(0.06)$ \\
\hline & & $\mathrm{BC}$ & Silt loam & $8.15(0.08)$ & $17.70(0.80)$ \\
\hline \multirow[t]{9}{*}{ Sandstone } & \multirow[t]{3}{*}{ Kahuta } & Ap & Sandy loam & $6.90(0.51)$ & $0.55(0.08)$ \\
\hline & & $\mathrm{Bw}$ & Sandy clay loam & $6.95(0.54)$ & $0.60(0.04)$ \\
\hline & & $\mathrm{Bt}$ & Sandy clay loam & $7.05(0.41)$ & $0.60(0.09)$ \\
\hline & \multirow[t]{3}{*}{ Balksar } & Ap & Loam & $7.65(0.11)$ & $1.90(0.72)$ \\
\hline & & Bw & Clay loam & $7.60(0.15)$ & $1.80(0.08)$ \\
\hline & & $\mathrm{Bt}$ & Clay loam & $7.60(0.24)$ & $3.20(2.57)$ \\
\hline & \multirow[t]{3}{*}{ Qazian } & Ap & Sandy loam & $7.60(0.06)$ & $8.85(0.72)$ \\
\hline & & Bw & Sandy loam & $7.60(0.08)$ & $10.15(0.08)$ \\
\hline & & $\mathrm{BC}$ & Sandy loam & $7.60(0.13)$ & $14.45(4.3)$ \\
\hline \multirow[t]{9}{*}{ Shale } & \multirow[t]{3}{*}{ Murree } & $\mathrm{A}$ & Silty clay loam & $6.55(0.45)$ & $0.94(0.21)$ \\
\hline & & Bw & Silty clay & $6.30(1.30)$ & $1.00(0.33)$ \\
\hline & & $\mathrm{Bt}$ & Silty clay & $6.40(1.30)$ & $0.80(0.25)$ \\
\hline & \multirow[t]{3}{*}{ Tirnul } & Ap & Clay loam & $7.60(0.12)$ & $13.30(0.92)$ \\
\hline & & Bw & Clay loam & $7.40(0.10)$ & $11.10(2.34)$ \\
\hline & & $\mathrm{Bk}$ & Silty clay & $7.55(0.17)$ & $8.80(2.46)$ \\
\hline & \multirow[t]{3}{*}{ Ghoragali } & $\mathrm{A}$ & Silty clay loam & $7.20(0.38)$ & $15.5(2.48)$ \\
\hline & & Bw & Silty clay loam & $7.45(0.14)$ & $14.05(4.3)$ \\
\hline & & $\mathrm{BC}$ & Silty clay & $7.55(0.16)$ & $14.30(3.4)$ \\
\hline
\end{tabular}


of exchangeable $\mathrm{K}$ than the soils at the early stage of development, whereas in sandstone and loess soils, the less developed soils had greater exchangeable $\mathrm{K}$ at all depths. Exchangeable $\mathrm{K}$ increased towards the soil surface (Table 3 ) and the hypothesis of no depth $\times$ soil (parent material) effect was accepted through MANOVA test criteria. The soils from three parent materials had drastically different textures. The shale-derived soils retain greater exchangeable $\mathrm{K}$ due to high clay content. Exchangeable $\mathrm{K}$ concentration differed significantly with the stage of soil development whereas it was nonsignificant with the depth. The less developed stages of loess Rajar and Rawalpindi had significantly greater exchangeable $\mathrm{K}$ than the highly developed Guliana soils. Same thing was observed in sandstone where less developed Qazian soils had more exchangeable $\mathrm{K}$ than the more developed Balkassar and Kahuta soils. The highest $\mathrm{K}$ concentration in the coarse fractions is attributed to the presence of biotite, muscovite and feldspar. The decrease in exchangeable $\mathrm{K}$ with development suggests reflects the depletion of $\mathrm{K}$ reserves.

\section{Non-exchangeable potassium}

The fraction of soil $\mathrm{K}$ extracted by boiling $\mathrm{HNO}_{3}$ is referred as non-exchangeable $\mathrm{K}$, which is trapped in the wedge structure of partially weathered mica and becomes available for plants uptake at last depletion stage, was highest in loess and lowest in sandstone derived soils. The difference among the parent materials remained statistically constant at all horizon level (Figure 1C) supported by the non-significant hypothesis of depth $\times$ parent material effect through MANOVA test criteria (Wilks' Lambda $\mathrm{P}>0.12$ ). The nonexchangeable $\mathrm{K}$ increased toward soil surface in all parent materials because of uptake of $\mathrm{K}$ by plants from lower horizons and continuous sedimentation of fresh mineral and organic materials through irrigation and eolian dust deposits on the soil surface. The
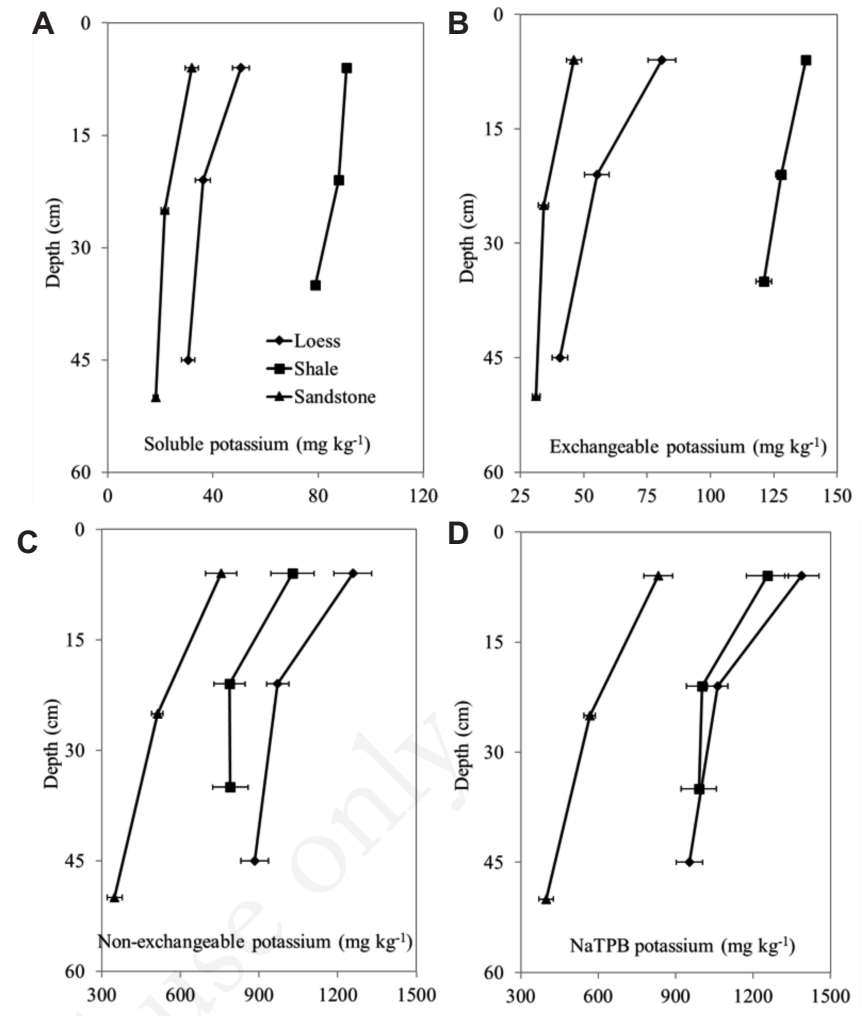

Figure 1. Vertical distribution of soluble potassium (A), exchangeable potassium (B), non-exchangeable potassium (C), and sodium tetraphenylborate potassium (D) in selected three parent material soils; error bars show the standard error.

Table 3. Distribution of soil potassium $\left(\mathrm{mg} \mathrm{kg}^{-1}\right)$ forms extracted using different extractants with depth in soils at different development stages in selected parent materials.

\begin{tabular}{|c|c|c|c|c|c|c|}
\hline Parent material & Soil series & Horizon & $\begin{array}{l}\text { Soluble K } \\
\text { (SD) }\end{array}$ & $\begin{array}{c}\text { Exchangeable K } \\
\text { (SD) }\end{array}$ & $\begin{array}{c}\text { Non-exchangeable } \mathrm{K} \\
\text { (SD) }\end{array}$ & $\begin{array}{l}\text { NaTPB K } \\
\text { (SD) }\end{array}$ \\
\hline Loess & $\begin{array}{l}\text { Guliana } \\
\text { Rawalpindi } \\
\text { Rajar }\end{array}$ & $\begin{array}{l}\text { Ap } \\
\text { Bw } \\
\text { Bt } \\
\text { Ap } \\
\text { Bw } \\
\text { Btk } \\
\text { Ap } \\
\text { Bw } \\
\text { BC }\end{array}$ & $\begin{array}{l}37(7) \\
22(4) \\
16(2) \\
67(4) \\
58(1) \\
48(4) \\
48(12) \\
28(1) \\
28(2)\end{array}$ & $\begin{array}{l}56(4) \\
35(7) \\
23(3) \\
113(9) \\
88(13) \\
60(9) \\
73(16) \\
43(2) \\
39(1)\end{array}$ & $\begin{array}{c}1429(208) \\
1066(118) \\
975(225) \\
980(289) \\
869(146) \\
798(159) \\
1364(122) \\
979(156) \\
875(137)\end{array}$ & $\begin{array}{c}1522(196) \\
1123(113) \\
1014(220) \\
1159(279) \\
1014(220) \\
906(157) \\
1486(113) \\
1051(157) \\
942(139)\end{array}$ \\
\hline Sandstone & $\begin{array}{l}\text { Kahuta } \\
\text { Balksar } \\
\text { Qazian }\end{array}$ & $\begin{array}{l}\mathrm{Ap} \\
\mathrm{Bw} \\
\mathrm{Bt} \\
\mathrm{Ap} \\
\mathrm{Bw} \\
\mathrm{Bt} \\
\mathrm{Ap} \\
\mathrm{Bw} \\
\mathrm{BC}\end{array}$ & $\begin{array}{l}27(4) \\
16(0) \\
17(2) \\
24(5) \\
19(0) \\
15(1) \\
45(9) \\
30(5) \\
23(3)\end{array}$ & $\begin{array}{l}42(7) \\
27(1) \\
26(1) \\
36(7) \\
29(0) \\
26(2) \\
60(10) \\
46(8) \\
42(4)\end{array}$ & $\begin{array}{c}728(264) \\
609(55) \\
356(81) \\
882(82) \\
460(83) \\
249(28) \\
656(203) \\
467(44) \\
442(120)\end{array}$ & $\begin{array}{c}797(257) \\
652(47) \\
399(83) \\
942(130) \\
507(83) \\
290(31) \\
761(188) \\
543(55) \\
507(110)\end{array}$ \\
\hline Shale & $\begin{array}{l}\text { Murree } \\
\text { Tirnul } \\
\text { Ghoragali }\end{array}$ & $\begin{array}{c}\text { A } \\
\text { Bw } \\
\text { Bt } \\
\text { Ap } \\
\text { Bw } \\
\text { Bk } \\
\text { A } \\
\text { Bw } \\
\text { BC }\end{array}$ & $\begin{array}{l}95(3) \\
94(3) \\
91(3) \\
89(5) \\
88(5) \\
74(4) \\
89(2) \\
81(2) \\
73(1)\end{array}$ & $\begin{array}{l}142(6) \\
140(6) \\
136(4) \\
132(3) \\
116(0) \\
98(5) \\
139(2) \\
127(1) \\
130(1)\end{array}$ & $\begin{array}{c}1068(329) \\
926(179) \\
788(187) \\
902(336) \\
774(286) \\
734(273) \\
1113(116) \\
661(10) \\
848(221)\end{array}$ & $\begin{array}{c}1304(330) \\
1159(175) \\
1014(191) \\
1123(332) \\
978(288) \\
906(270) \\
1341(113) \\
870(15) \\
1051(229)\end{array}$ \\
\hline
\end{tabular}

Soluble K, potassium extracted with deionised water; SD, standard deviation; exchangeable K, potassium extracted with $1 \mathrm{M}$ ammonium acetate; non-exchangeable K, potassium extracted with boiling nitric acid; NaTPB K, potassium extracted with sodium tetraphenylborate. 
sandstone is mostly composed of quartz, whereas the loess contains mica and $\mathrm{K}$ feldspar (Akhtar and Dixon, 2009). The soils at an early stage of development release more non-exchangeable $\mathrm{K}$ than highly weathered soils due to the presence of weatherable minerals (Pratt, 1951). The soils at early stage of development had a larger amount of non-exchangeable $\mathrm{K}$ than the soils at the higher stage of development because of occurrence of large amount of mica in less developed and younger soils. The non-exchangeable $\mathrm{K}$ increased toward the soil surface with a greater magnitude of difference in more weathered soils (Table 3 ). The hypothesis of no depth $\times$ soil (parent material) effect was accepted by MANOVA test criteria. The loess-derived soils had significantly greater amount of non-exchangeable $\mathrm{K}$ as compared to shale and sandstone at all depths.

\section{Sodium tetraphenylborate extractable potassium}

The NaTPB extracts plant available $\mathrm{K}$ from soil that includes non-exchangeable and exchangeable $\mathrm{K}$. This $\mathrm{K}$ fraction was recorded in the range of 543 to $1630 \mathrm{mg} \mathrm{kg}^{-1}$ in the loess soils, 217 to $1195 \mathrm{mg} \mathrm{kg}^{-1}$ in the sandstone soils and 435 to $1740 \mathrm{mg} \mathrm{kg}^{-1}$ in the shale soils. The hypothesis of non-significant depth $\times$ parent material effect was accepted by MANOVA test criteria implying that the difference in parent materials remained statistically significant at all horizon levels (Figure 1D). The NaTPB can extract fixed interlayer $\mathrm{K}$ from micaceous minerals as it maintains an extremely low $\mathrm{K}$ concentration in a soil solution thereby accelerating the exchange of interlayer $\mathrm{K}$. This process resembles the removal of $\mathrm{K}$ from mica that may occur in the $\mathrm{K}$ depleted soil solution in the rhizosphere (Hinsinger et al., 1993). However, NaTPB is quite ineffective in removing $\mathrm{K}$ from the three-dimensional structure of K-feldspar (Song and Huang, 1988).

The soils at early stage of development had a larger amount of $\mathrm{K}$ than the soils at the higher stage of development and the NaTPB
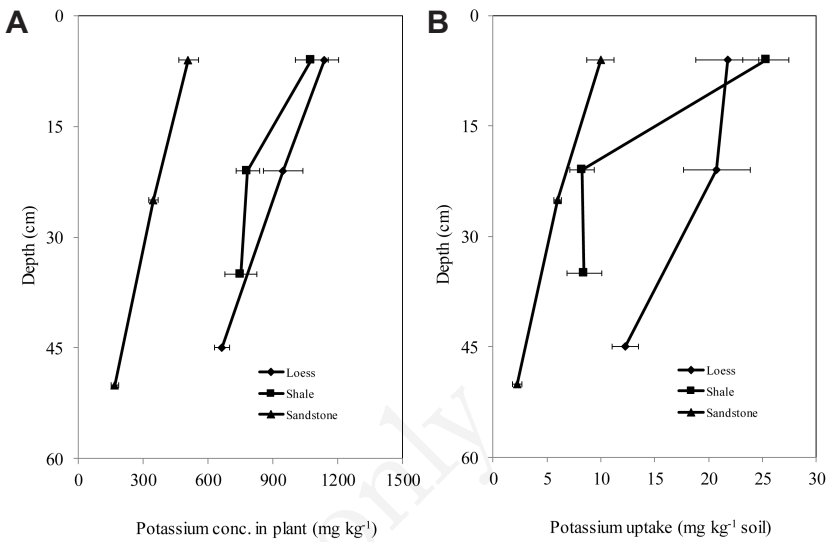

Figure 2. Vertical distribution of potassium concentration in plant (A) and potassium uptake (B); error bars show the standard error.

Table 4. Distribution of plant potassium concentration and uptake with depth in soils at different development stages in selected parent materials.

\begin{tabular}{|c|c|c|c|c|}
\hline Parent material & Soil series & Horizon & $\begin{array}{l}\text { Plant } \mathrm{K} \text { concentration } \\
\text { ( } \mathrm{mg} \mathrm{kg}^{-1} \text { dry matter) (SD) }\end{array}$ & $\begin{array}{c}\text { Plant K uptake } \\
\text { (mg kg-1 soil) (SDK) }\end{array}$ \\
\hline Loess & $\begin{array}{l}\text { Guliana } \\
\text { Rawalpindi } \\
\text { Rajar }\end{array}$ & $\begin{array}{l}\mathrm{Ap} \\
\mathrm{Bw} \\
\mathrm{Bt} \\
\mathrm{Ap} \\
\mathrm{Bw} \\
\mathrm{Btk} \\
\mathrm{Ap} \\
\mathrm{Bw} \\
\mathrm{BC}\end{array}$ & $\begin{array}{c}1357(198) \\
841(189) \\
613(85) \\
853(241) \\
1246(438) \\
660(106) \\
1210(76) \\
759(135) \\
724(155)\end{array}$ & $\begin{array}{c}26(8) \\
13(3) \\
12(3) \\
12(2) \\
14(2) \\
13(1) \\
27(14) \\
17(6) \\
16(6)\end{array}$ \\
\hline Sandstone & $\begin{array}{l}\text { Kahuta } \\
\text { Balksar } \\
\text { Qazian }\end{array}$ & $\begin{array}{l}\mathrm{Ap} \\
\mathrm{Bw} \\
\mathrm{Bt} \\
\mathrm{Ap} \\
\mathrm{Bw} \\
\mathrm{Bt} \\
\mathrm{Ap} \\
\mathrm{Bw} \\
\mathrm{BC}\end{array}$ & $\begin{array}{c}499(43) \\
472(0) \\
77(43) \\
666(174) \\
297(62) \\
165(43) \\
472(172) \\
349(70) \\
232(37)\end{array}$ & $\begin{array}{l}14(5) \\
6(1) \\
2(0) \\
8(3) \\
6(1) \\
1(0) \\
8(3) \\
6(1) \\
5(1)\end{array}$ \\
\hline Shale & $\begin{array}{l}\text { Murree } \\
\text { Tirnul } \\
\text { Ghoragali }\end{array}$ & $\begin{array}{c}\text { A } \\
\text { Bw } \\
\text { Bt } \\
\text { Ap } \\
\text { Bw } \\
\text { Bk } \\
\text { A } \\
\text { Bw } \\
\text { BC }\end{array}$ & $\begin{array}{c}885(216) \\
806(210) \\
727(217) \\
1093(299) \\
707(192) \\
730(286) \\
1298(201) \\
630(154) \\
402(98)\end{array}$ & $\begin{array}{l}26(9) \\
9(3) \\
9(3) \\
24(2) \\
12(0) \\
11(5) \\
26(9) \\
12(5) \\
5(2)\end{array}$ \\
\hline
\end{tabular}

Plant $\mathrm{K}$ concentration, potassium concentration in dry matter of maize plant; SD, standard deviation; plant K uptake, potassium uptake from one kg of soil by maize plant was obtained by multiplying dry matter with plant potassium concentration. 
extracted $\mathrm{K}$ increased toward the soil surface. The loess-derived soils had significantly greater amount of NaTPB-extracted $\mathrm{K}$ as compared to shale and sandstone at all depths (Table 3). The hypothesis of no depth $\times$ soil (parent material) effect was accepted through MANOVA test criteria. The analysis result showed that NaTPB extracts greater amount of $\mathrm{K}$ as compared to other methods. The NaTPB method has the potential of describing the plant available $\mathrm{K}$ status of soils more completely as compare to the other methods. The NaTPB-extracted $\mathrm{K}$ is a better indicator of plant $\mathrm{K}$ uptake than $1 \mathrm{M} \mathrm{NH}_{4} \mathrm{OAc}$ extracted $\mathrm{K}$ because of the later's inability to measure plant available non exchangeable K (Cox and Joern, 1996). The extent and rate of $K$ release to NaTPB from the soil clays are highly dependent on the clay mineralogy. The amounts and rates of $\mathrm{K}$ release from illite-containing clay are much higher than for clay containing only kaolinite with or without inhibited vermiculite (Darunsontaya et al., 2010).

\section{Plant potassium concentration and uptake}

Potassium concentration in maize plants ranged from 450 to $1740 \mathrm{mg} \mathrm{kg}^{-1}$ on the loess soils, 15 to $900 \mathrm{mg} \mathrm{kg}^{-1}$ on the sandstone soils and 300 to $1400 \mathrm{mg} \mathrm{kg}^{-1}$ on the shale soils. It is apparent that plants grown on loess soils were able to extract more K. The hypothesis of non-significant depth $\times$ parent material effect was accepted by MANOVA test criteria suggesting that the difference in $\mathrm{K}$ concentration at corresponding depth remained statistically same for the parent materials. Potassium concentration increased toward the surface in all parent materials when averaged over different soils in each parent material separately (Figure 2A). Particle size of $\mathrm{K}$ minerals and their structural characteristics influence the $\mathrm{K}$ release from soil minerals (Huang, 2005). The sandstone is mostly composed of quartz and contains lesser weather- able minerals. The loess contains greater mica and K-feldspar. Shale contains fewer and lesser crystalline biotite. Trioctahedral mica minerals such as biotite and phlogopite release K more readily than dioctahedral such as muscovite (Fanning et al., 1989). Fine particles undergo layer weathering which results in rapid release of $\mathrm{K}$ whereas large-size particles undergo edge weathering and proceed slowly to completely vermiculitised (Huang, 2005).

The hypothesis of no depth $\times$ soil (parent material) was accepted through MANOVA test criteria (Wilks' Lambda P>0.57) implying that the soils at different development stages do not differ drastically in K supply. In all the three parent material soils, the plants that were sown in first horizon soils had more $\mathrm{K}$ concentration compared to the second and third horizon as $\mathrm{K}$ concentration in plants decrease with depth (Table 3). Further, the plants sown in soils at higher stage of development in loess had larger amount of $\mathrm{K}$ than soil at the early stage of development, whereas plants sown in sandstone and shale soils had more K concentration in the less developed soils.

The $\mathrm{K}$ uptake of plants ranged from 1 to $30 \mathrm{mg} \mathrm{kg}^{-1}$ in loess soils, 0.1 to $9 \mathrm{mg} \mathrm{kg}^{-1}$ in sandstone soils and 1 to $20 \mathrm{mg} \mathrm{kg}^{-1}$ soils on shale soils. Plants differ in their ability to take up $\mathrm{K}$ depending on several factors, these factors are soil factors as well as plant factors, the soil factors include CEC, soil moisture, available and nonexchangeable $\mathrm{K}$ content of soil etc., whereas plant factors include hybrid and plant population. The plants in first horizon soils uptake more K followed by second and third horizon soils (Table 3). The first horizon plants of shale uptake more $\mathrm{K}$ followed by loess and sandstone, whereas in second horizon the plants of loess uptake large amount of $\mathrm{K}$ as compare to shale and sandstone because the mica content of loess is more weathered and other soils had mica in crystalline form.
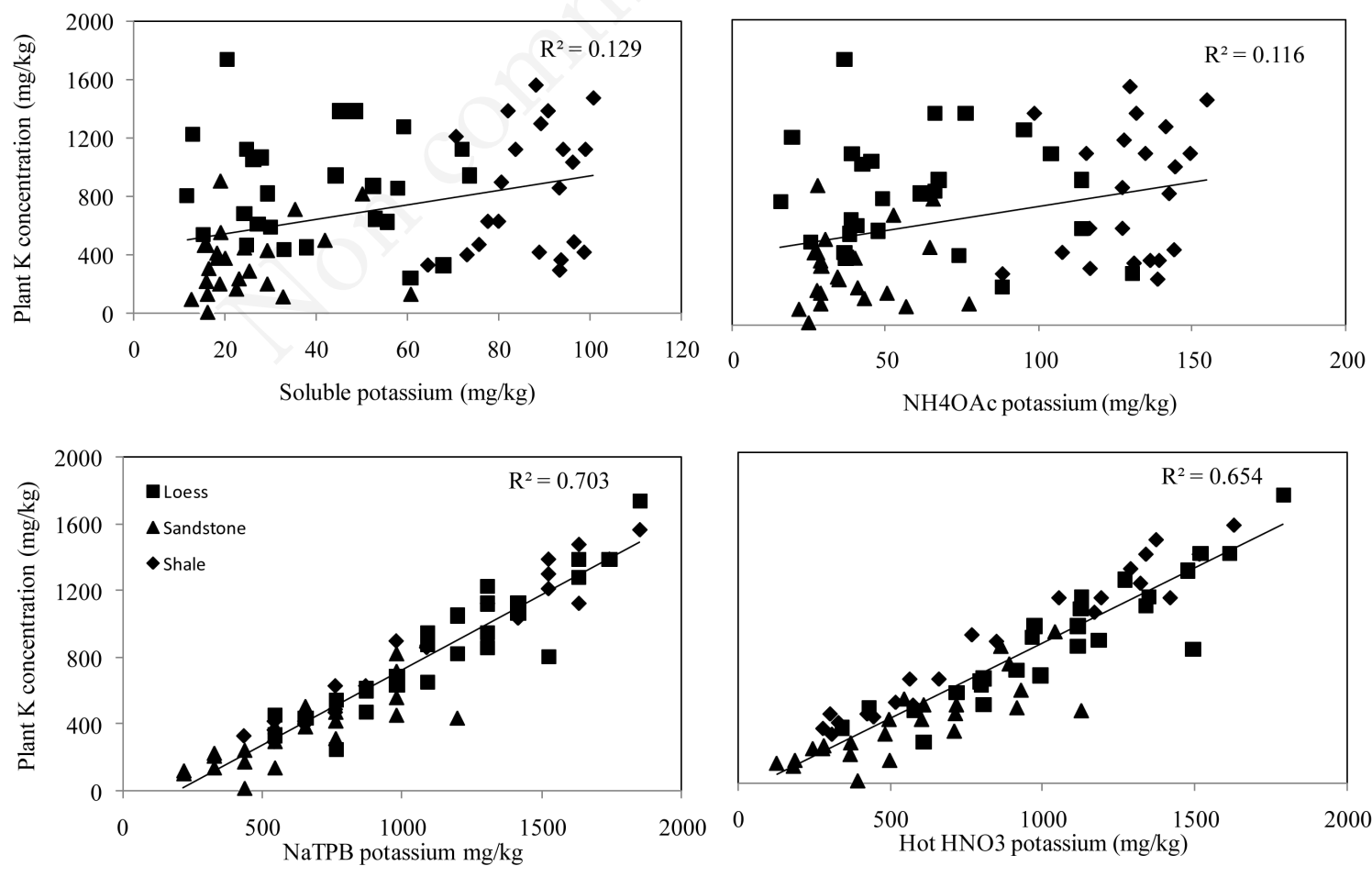

Figure 3. Relationship between plant potassium concentrations $\left(\mathrm{mg} \mathrm{kg}^{-1}\right)$ and different potassium forms extracted with different extractants $\left(\mathrm{mg} \mathrm{kg}^{-1}\right)$. 

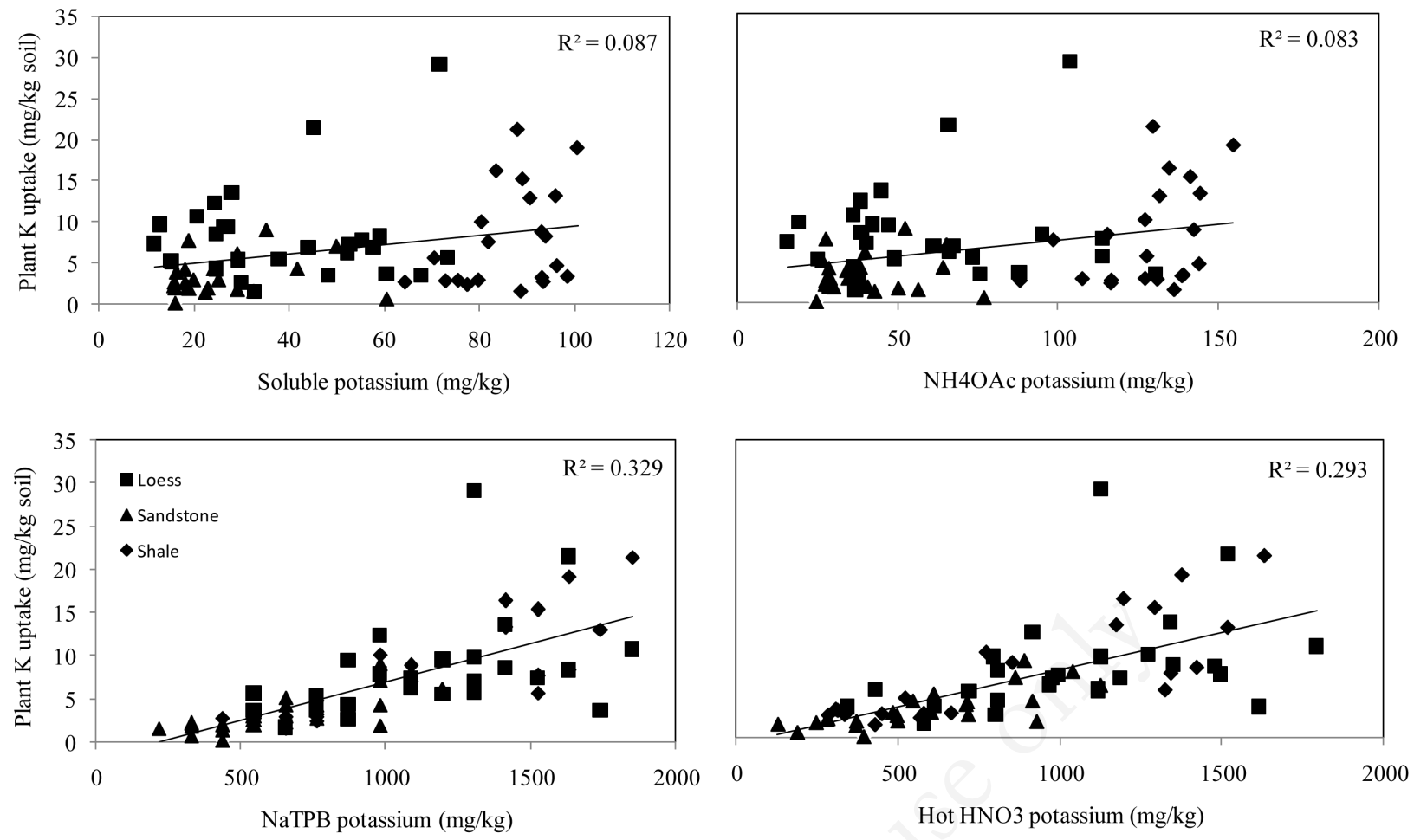

Figure 4. Relationship between plant potassium uptake $\left(\mathrm{mg} \mathrm{kg}^{-1}\right)$ and different potassium forms extracted with different extractants $\left(\mathrm{mg} \mathrm{kg}^{-1}\right)$.

\section{Relationship of plant potassium with potassium extracted with different extractants}

The $\mathrm{K}$ concentration in plant and $\mathrm{K}$ uptake by plant better correlated with NaTPB-extracted $\mathrm{K}\left(\mathrm{R}^{2} 0.703\right.$ and 0.329$)$ than with $\mathrm{NH}_{4} \mathrm{OAc}$-extracted $\mathrm{K}\left(\mathrm{R}^{2} 0.129\right.$ and 0.087$)$ in all soils, respectively (Figures 3 and 4, Table 4). This confirms that a non-exchangeable $\mathrm{K}$ portion is only assessable to NaTPB test but not to $\mathrm{NH}_{4} \mathrm{OAc}$. According to Mengel and Uhlenbecker (1993), this non-exchangeable $\mathrm{K}$ trapped between interlayer of clay minerals is a major source of $\mathrm{K}$ for plants grown on many soils. The availability of non-exchangeable $\mathrm{K}$ depends primarily on the release rate of $\mathrm{K}$ from the interlayer of clay minerals. Besides illite, the $\mathrm{K}$ fixing capacity also seemed to have its influence on non-exchangeable $\mathrm{K}$ release. These relationships indicate that plants uptake solution $\mathrm{K}$ then exchangeable $\mathrm{K}$ is available to plants. The non-exchangeable $\mathrm{K}$ was not readily available but when solution $\mathrm{K}$ is depleted then non-exchangeable $\mathrm{K}$ can be a source of $\mathrm{K}$ for plants that maintains the solution concentration after exchangeable K. The NaTPB method has the potential of describing the plant-available $\mathrm{K}$ status of soils more completely than does soil test K, exchangeable $\mathrm{K}$ or extractable K.

\section{Conclusions}

The correlation between NaTPB-extracted $\mathrm{K}$ and plant $\mathrm{K}$ concentration and uptake was stronger than with the $\mathrm{NH}_{4} \mathrm{OAc}$-extracted $\mathrm{K}$ method. The study reveals that a non-exchangeable $\mathrm{K}$ fraction may become available to plants that can only be estimated by
NaTPB method. In conclusion, the NaTPB method has an advantage over the $\mathrm{NH}_{4} \mathrm{OAc}$ method for the assessment of the plant available $\mathrm{K}$.

\section{References}

Akhtar MS, 1989. Soil mineralogy and potassium quantity/ intensity relations in the alluvial soils from Pakistan. Degree Diss., Texas A\&M University, College Station, TX, USA.

Akhtar MS, Dixon JB, 2009. Mineralogical characteristics and potassium quantity/intensity relation in three Indus River basin soils. Asian J. Chem. 21:3427-42.

Akhtar MS, Imran M, Mehmood A, Memon M, Rukh S, Kiani GS, 2014. Apatite loss in Pothwar Loess Plain (Pakistan) fits a simple linear reservoir model. Pedosphere 24:763-75.

Bajwa MF, 1989. Potassium mineralogy of Pakistani soils and its effect on potassium response. Proc. Workshop on the Role of Potassium in Improving Fertilizer Use Efficiency. National Fertilizer Development Center, Islamabad, Pakistan, pp. 20316.

Bhaskar BP, Vadivelu S, Baruah U, Bhutte PS, Dutta DP, 2001. Distribution of potassium forms and chars and marshy soils of Brahmaputra valley, Jorhat district, Assam. J. Potassium Res. 17:39-47.

Chapman HD, Pratt PF, 1961. Methods of analysis for soils, plants and water. University of California, Berkely, CA, USA.

Cox AE, Joern BC, 1996. Predicting plant available potassium using a modified sodium tetraphenylboron method. Proc. North Central Extension-Industry Soil Fertility Conference. 
Vol. 12. St. Louis, MI, USA, pp. 70-81.

Cox AE, Joern BC, 1997. Release kinetics of nonexchangeble potassium in soils using sodium tetraphenylboron. Soil Sci. 162:588-98.

Cox AE, Joern BC, Brounder SM, Gao D, 1999. Plant-available potassium assessment with a modified sodium tetraphenylboron method. Soil Sci. Soc. Am. J. 63:902-11.

Darunsontaya T, Suddhiprakarn A, Kheoruenromne I, Gilkes RJ, 2010. A comparison of extraction methods to assess potassium availability for Thai upland soils. Proc. $19^{\text {th }}$ World Congress of Soil Science, Soil Solutions for a Changing World, Brisbane, Australia, pp. 1-4.

Fanning DS, Keramidas VZ, El-Desoky MA, 1989. Micas. In: J.B. Dixon, S.B. Weed (eds.) Minerals in soil environments. Soil Science Society of America, Madison, WI, USA, pp. 551-634.

Fernandez FG, Brouder SM, Beyrouty CA, Hoyum R, 2008. Assessment of plant-available potassium for no-till, rainfed soybean. Soil Sci. Soc. Am. J. 72:1085-95.

Herlihy M, 1992. Field evaluation of soil tests for K: quantity, intensity, EUF-K and other soil properties. Commun. Soil Sci. Plant Anal. 23:2295-12.

Hinsinger P, Elsass F, Jaillard B, Robert M, 1993. Root-induced irreversible transformation of trioctahedral mica in the rhizosphere of rape. J. Soil Sci. 44:535-45.

Hosseinpour A, Sinegani AAS, 2004. Evaluating garlic available potassium with chemical extractants. Commun. Soil Sci. Plant Anal. 35:2147-59.

Hosseinpur AR, Samavati M, 2008. Evaluation of chemical extractants for the determination of available potassium. Commun. Soil Sci. Plant Anal. 39:1559-70.

Huang PM, 2005. Chemistry of potassium in soils. In: M.A. Tabatabai, D.L. Sparks (eds.) Chemical processes in soils. Soil Science Society of America, Madison, WI, USA, pp. 227-92.

Jackson ML, 1973. Soil chemical analysis. Prentice Hall Inc., New Delhi, India.

Jamil S, Mehmood A, Akhter MS, Memon M, Imran M, Rukh S, Qayyum A, Jenks MA, 2016. Changes in soil phosphorus fractions across a toposequence in the estuary plains of Pakistan. Arch. Agron. Soil Sci. 62:1567-77.

Kilic K, Derici MR, Saltali K, 1999. The ammonium fixation in great soil groups of Tokat Region and some factors affecting the fixation I. The affect of potassium on ammonium fixation. Turk. J. Agric. For. 23:673-8.
Knudsen D, Peterson GA, Pratt PF, 1996. Lithium, Sodium and Potassium. In: A.L. Page (ed.) Methods of soil analysis. Part 2. 2nd ed. American Society of Agronomy, Madison, WI, USA, pp. 403-29.

Leoppert RH, Hallmark CT, Koshy MM, 1984. Routine procedure for rapid determination of soil carbonates. Soil Sci. Soc. Am. J. 48:1030-33.

Mehmood A, Akhtar MS, Khan KS, Khalid A, Imran M, Rukh S, 2015. Relationship of Phosphorus Uptake with its Fractions in Different Soil Parent Materials. Int. J. Plant Soil Sci. 4:46-53.

Mengel K, Uhlenbecker K, 1993. Determination of available interlayer potassium and its uptake by ryegrass. Soil Sci. Soc. Am. J. 57:761-66.

Pratt PF, 1951. Potassium removal from Iowa soils by greenhouse and laboratory procedures. Soil Sci. 72:107-18.

Pratt PF, 1965. Potassium. In: C.A. Black (ed.). Methods of soil analysis. Part 2: Chemical and microbiological properties. American Society of Agronomy, Madison, WI, USA, pp. 1023-31.

Ranjha AM, Mehdi SM, Qureshi RH, 1992. Potassium behavior in some alluvial soil series of Pakistan. Pak. J. Agric. Res. 30:101-10.

Ruiz JM, Romero L, 2002. Relationship between potassium fertilization and nitrate assimilation in leaves and fruits of cucumber (cucumis sativus) plants. Annal. Appl. Boil. 140:241-5.

Schindler FV, Woodard HJ, Doolittle JJ, 2002. Plant available potassium assessment through chemical prediction methods. Commun. Soil Sci. Plant Anal. 33:1473-84.

Setia RK, Sharma KN, 2004. Vertical distribution of chemical pools of potassium and their relationship with potassium nutrition of wheat under long-term differential fertilization. J. Indian. Soc. Soil Sci. 55:469-72.

Simard RR, Zizka J, 1994. Evaluating plant available potassium with strontium citrate. Commun. Soil Sci. Plant Anal. 25:1779-89.

Song SK, Huang PM, 1988. Dynamics of potassium release from potassium-bearing minerals as influenced by oxalic and citric acids. Soil Sci. Soc. Am. J. 52:383-90.

Srinivassarao CA, Ganeshamurthy N, Ali M, Singh RN, Singh KK, 2002. Distribution of different forms of potassium in different pulse growing regions of India. J. Potassium. Res. 18:23-30.

Thomas GW, 1996. Soil pH and Soil Acidity. In: D.L. Sparks (ed.) Methods of soil analysis. Part 3. Soil Science Society of America, Madison, WI, USA, pp. 475-90. 